\title{
Notas do Jardim Selvagem
}

\section{Danna Lua Irigaray}

(Aos que habitam arredores fronteiras)

cartografia para leitura

Atlas

Nomadismo Doméstico

$\mathrm{O}$ jardim selvagem

Na boca do rio e debaixo do para-raios 
Atlas ${ }^{1}$

Coleção de cartas geográficas.

Coleção de estampas, elucidativas de obra, a que estão anexas.

A primeira vértebra superior. 


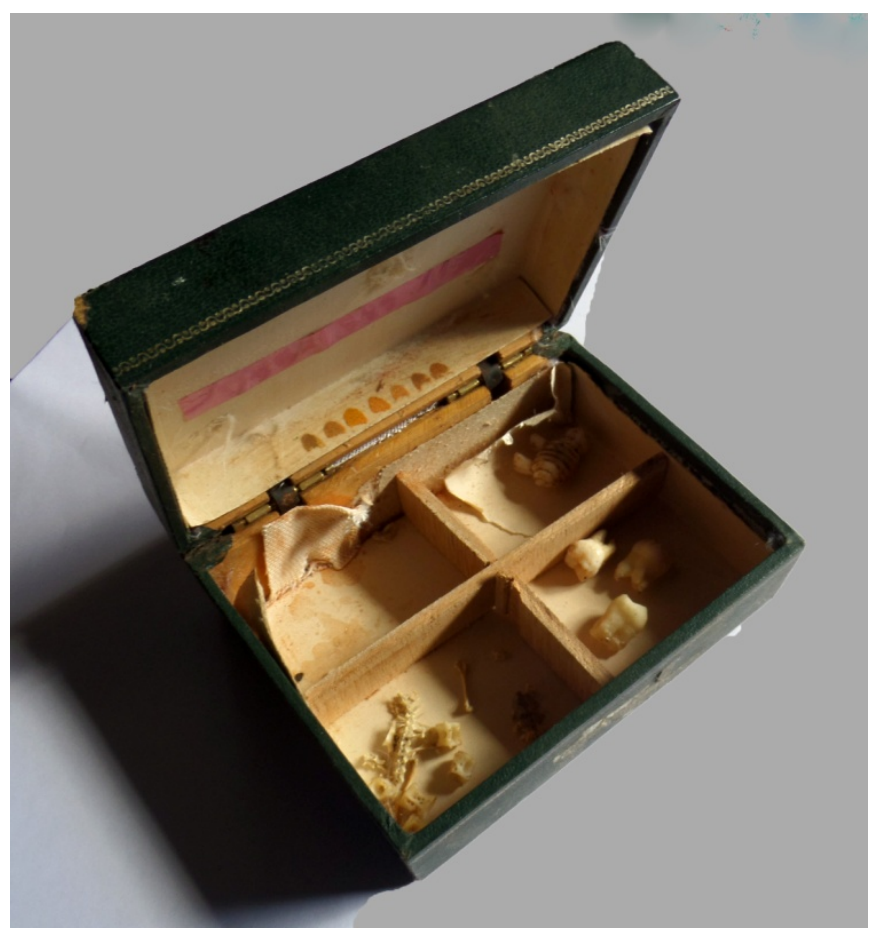

Escavações do micro-cosmos.

Danna Lua Irigaray. 2015 


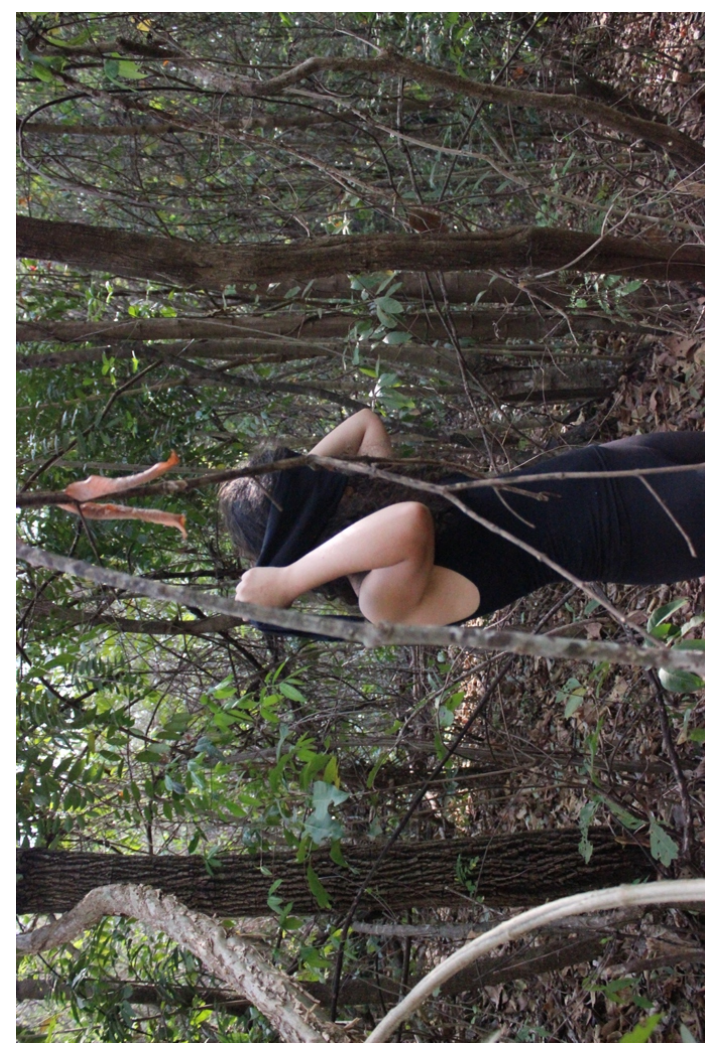

Anos-sombra: em busca do meteoro.

Danna Lua Irigaray. 2015 


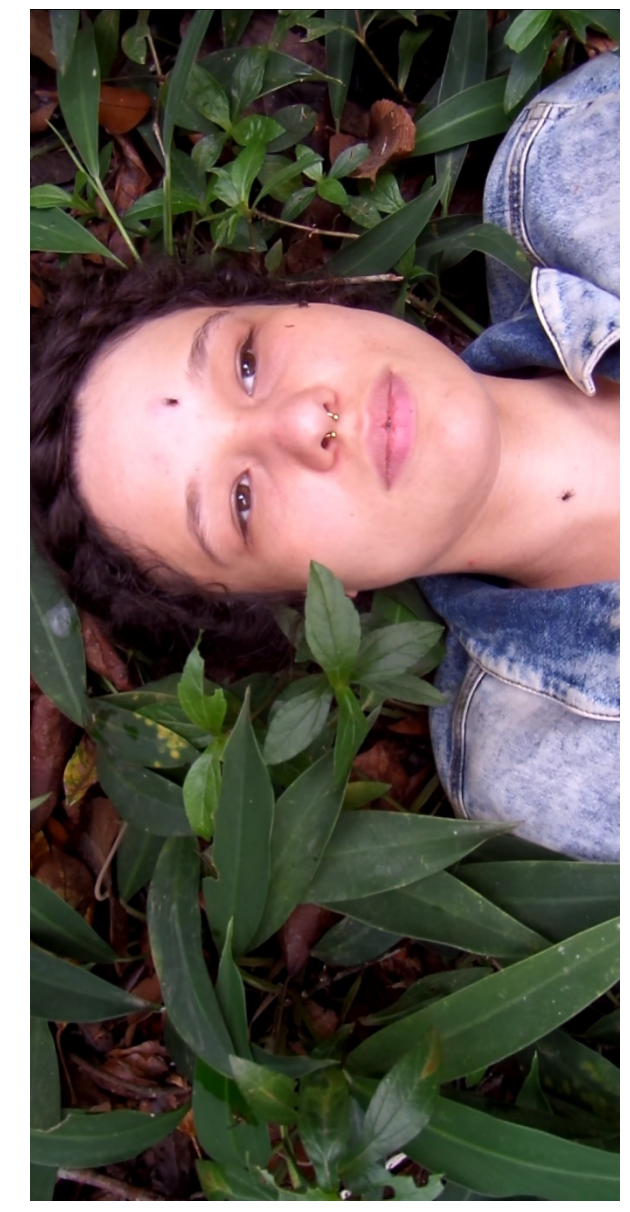

Selvagem: às moscas. 16'30'”.

Danna Lua Irigaray. 2015 

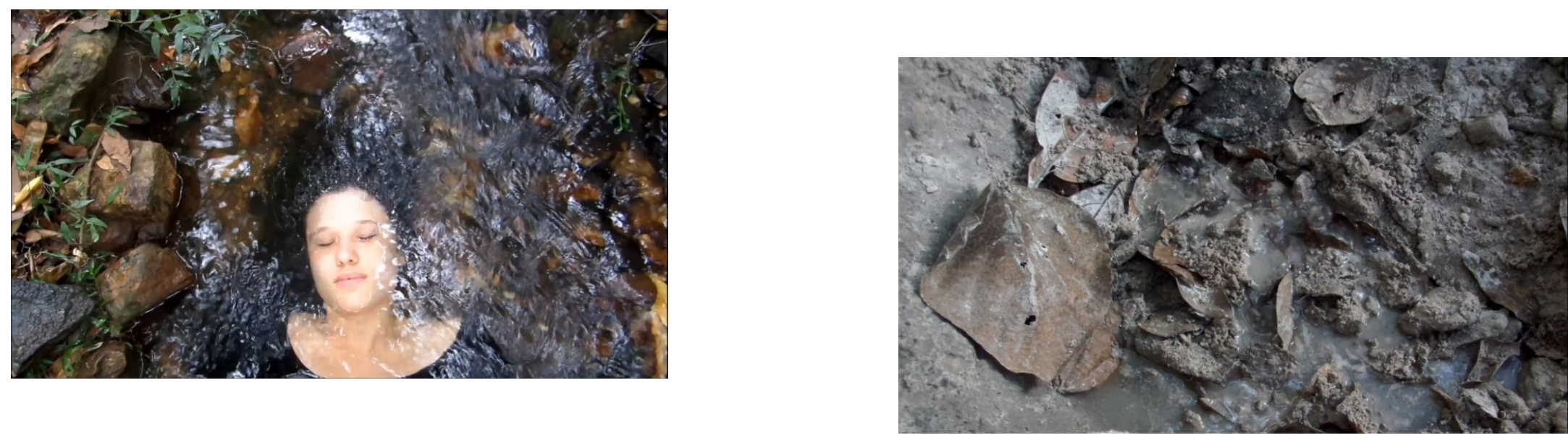

Dilúvios. 10'02" e 6'59'.

Danna Lua Irigaray. 2015 

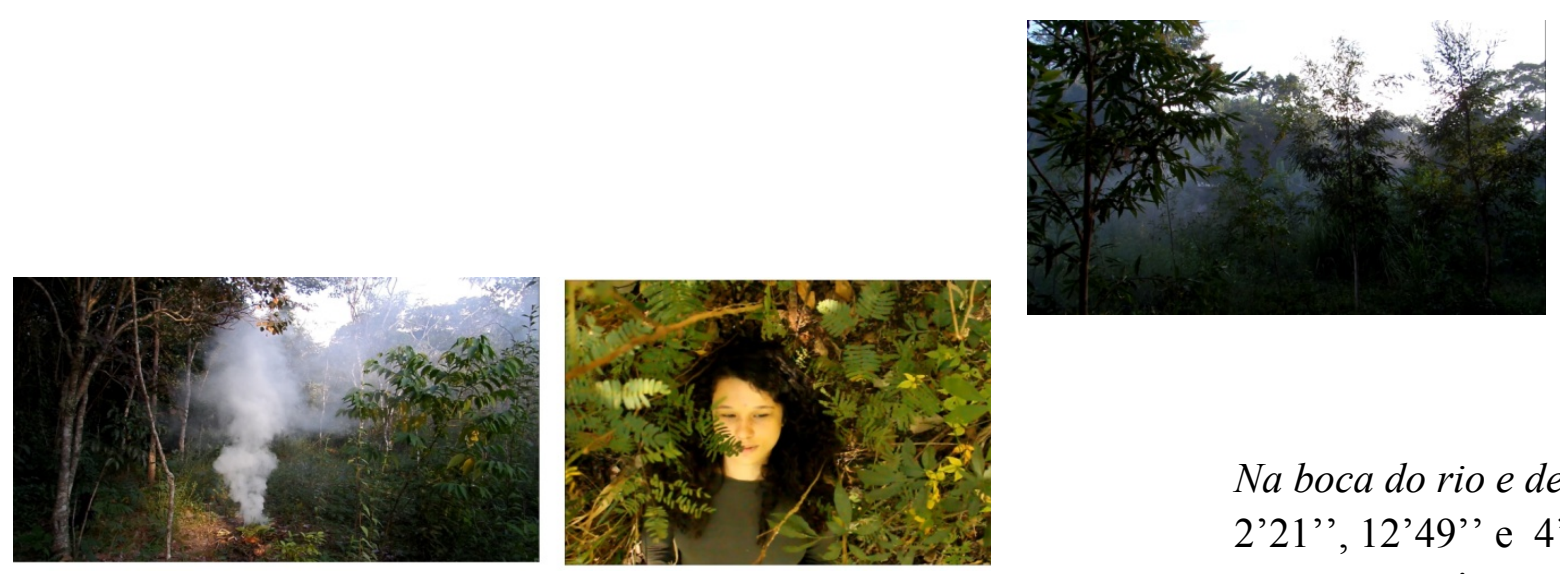

Na boca do rio e debaixo do para-raios.

2'21', 12'49', e 4'01'.

Danna Lua Irigaray. 2016 

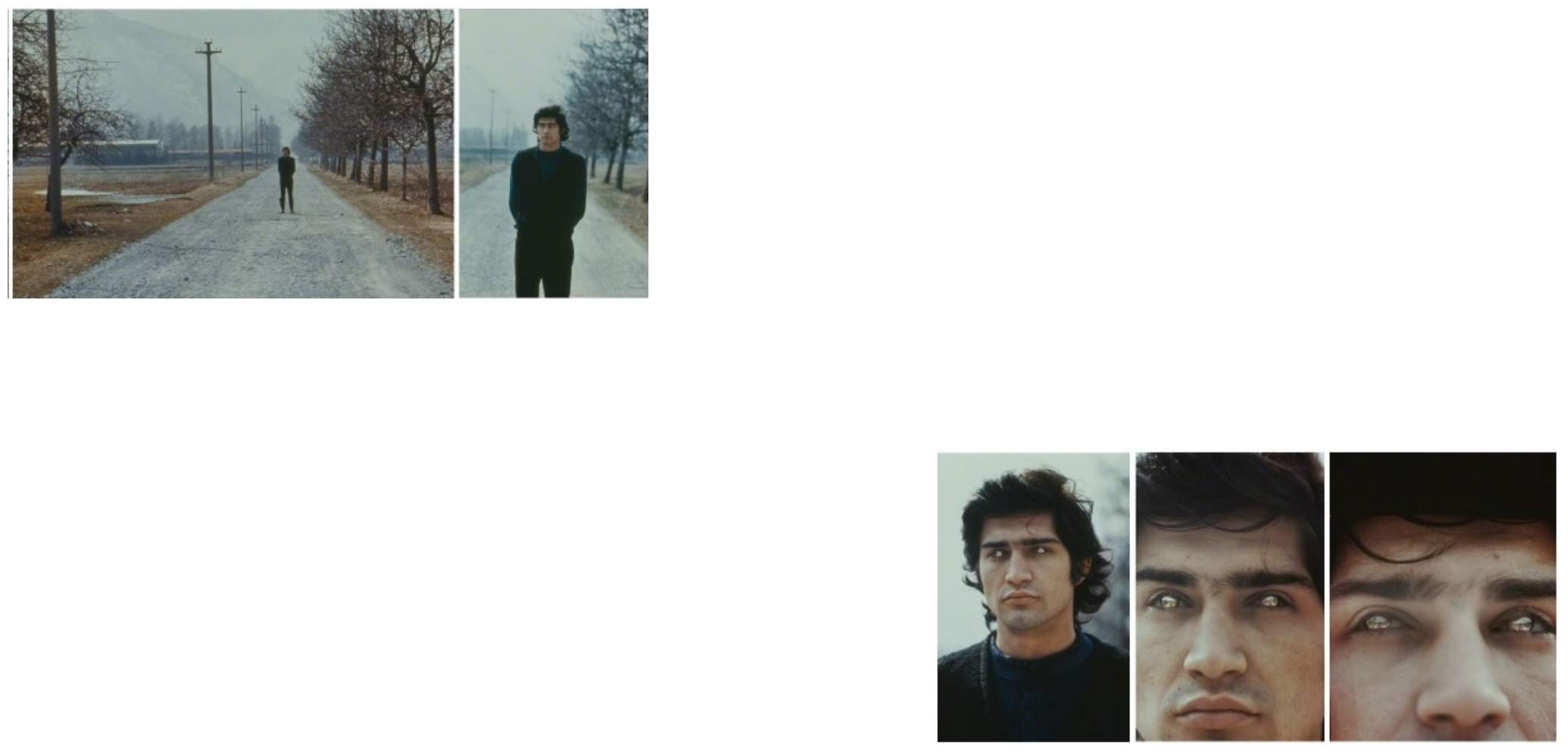

To reverse one's eyes. 
Giuseppe Penone.1970

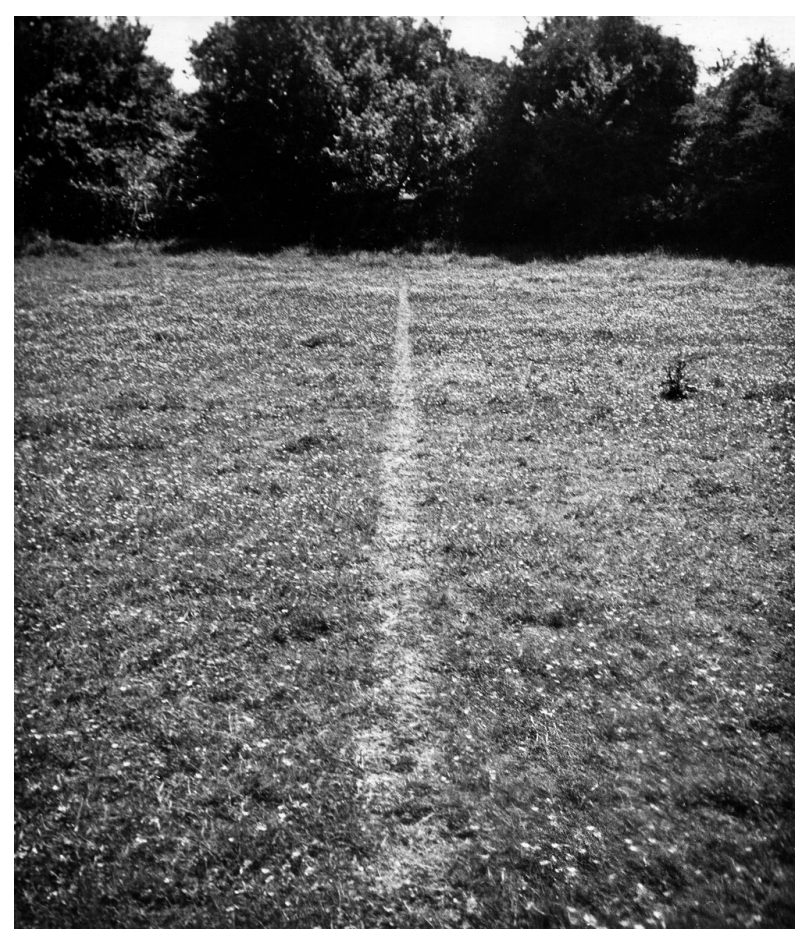

A line made by walking.

Richard Long. 1967 


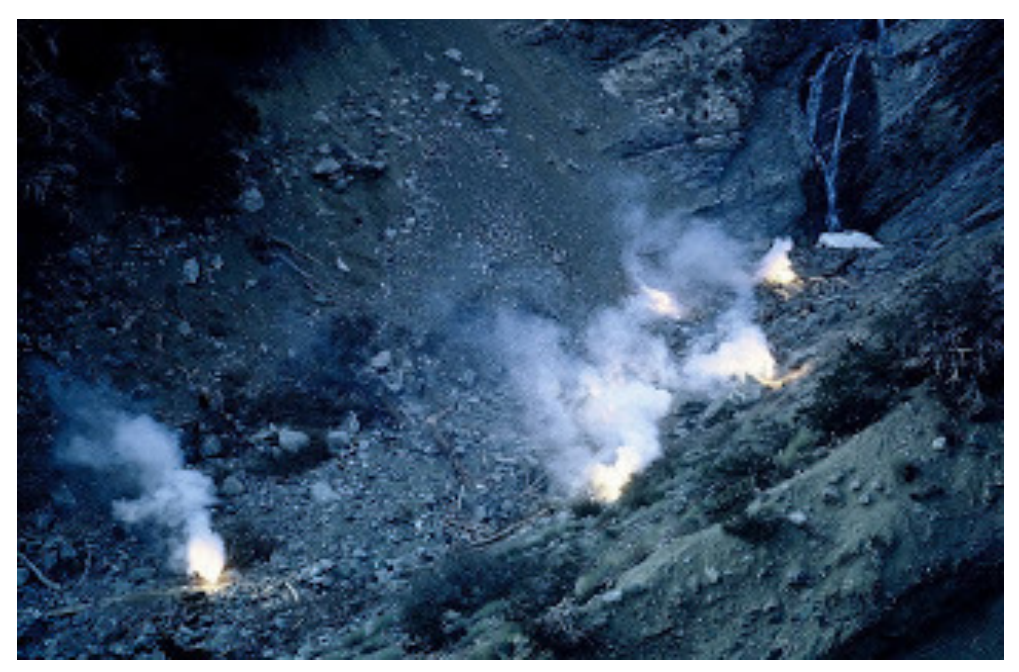


Snow Atmosphere.

Judy Chicago.1970

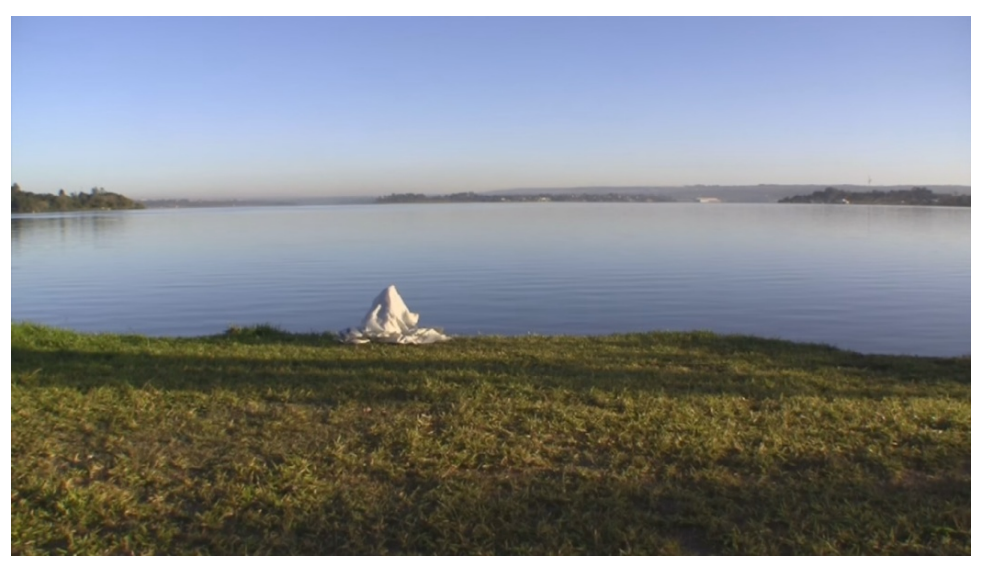


Pequeniníssimas navegações. 10'38',

Nina Orthof. 2013

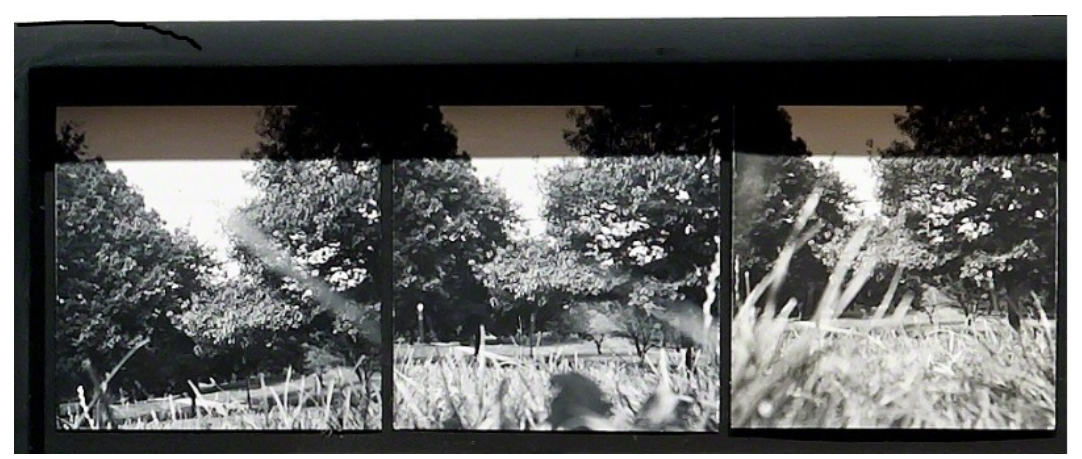




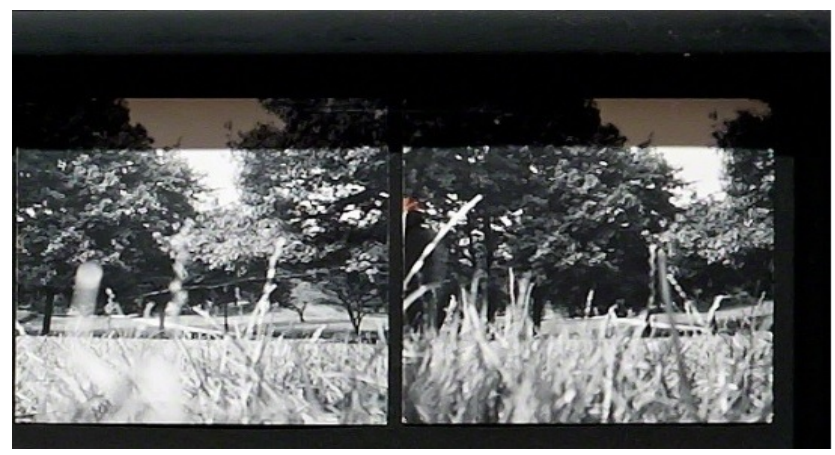

Lay oh the Land.

Vito Acconci. 1969
As notas são maneiras de apanhar o sentido que surge das ideias, de não deixá-lo escapar. Sua duração é breve, em contraposição ao tempo longo das demoras da terra para os quais eu olho.

O texto é um acontecimento constitutivo da obra e parte da cartografia que dá contornos ao território íntimo e seus arredores, que abrigam minha produção poética .

As obras de outros artistas, escritos e poemas aparecem aqui como notas de pensamento, presentes no texto pela imagem, poesia e diálogo. 


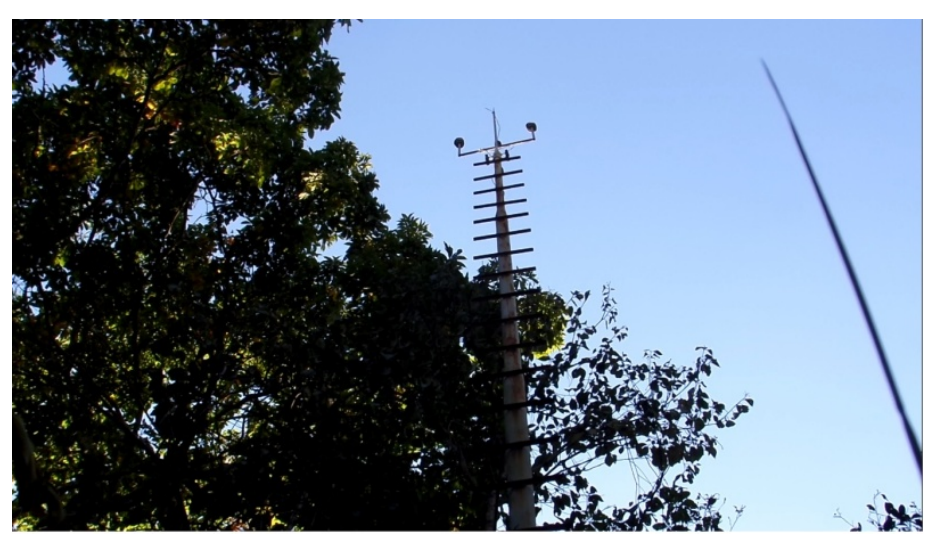

Para-raios.

Danna Lua Irigaray. 2016
Por tanto tempo te construí, ó casa! A cada lembrança eu transportava pedras Do riacho para o alto de tuas paredes

E via, colmo curtido pelas estações do ano, Teu telhado mutável como o mar

Dançar no fundo das nuvens

A que misturava sua fumaça

Casa de vento, morada que um sopro apagava.

(Louis Guillaume) 


\section{Nomadismo Doméstico}

O caminho

Eu sei de cor

Da base ao topo 
Uma casa perto do chão.

Como nomear o simples habitar- fora das paredes, dentro do corpo, dentro da fronteira, fora do mundo. O que é o quintal dentro do cosmos, que constitui um universo e seu mapa é uma constelação de coisas pisadas, de vazios que abrigam os corpos das árvores e das pedras, como o meu próprio corpo as abriga, ao passo que abrigo a casa de fora como também me habita uma casa por dentro em devir e entrelaçamentos.

Tive um sonho que na floresta do meu quintal havia uma casa pequena, com outra casa dentro que era maciça. Essa casa ia ser habitada por outra pessoa.
Assim como esse texto, que mapeando a minha casa, se torna transitável, habitável, adentrável.

(são processos de chão e de céu também) 
quintal , um quintal não domesticado e ainda doméstico. Ele é ainda a casa.

A casa se abre para o mundo².

\section{Nômade}

Sem lugar

Bachelard apresenta as coisas postas em seus lugares pela atividade doméstica. Observo aqui as coisas com lugares feitos pelo vento e pela gravidade - a ação geológica observada como ação doméstica, uma vez que ocorrem no

2 BACHELARD, G. A poética do espaço. São Paulo: Ed. Martins fontes, 1993 
As notas do jardim selvagem foram feitas em momentos e escavações no próprio, o jardim, fora de casa e em reflexões e diálogos posteriores, dentro de casa.

As notas do jardim selvagem assumem a qualidade nômade das palavras, em significados e sentidos transitórios, que se cabem enquanto puderem caber.

As frases e imagens acontecem em diálogos que tateiam as palavras elas mesmas, trazendo-as para cá com as pontas dos dedos, as unhas sujas de poeira das escavações em papel.

\section{ISSN 2448-1246}

Os nomes dos minerais e os próprios minerais não se diferem, porque no fundo tanto do material quanto do sinal impresso está o começo de um numero abissal de fissuras. Palavras e rochas contém uma linguagem que segue a sintaxe de fendas e rupturas. Olhe pra qualquer palavra por bastante tempo e você vai vê-la se abrir em uma série de falhas, em um terreno de partículas, cada uma contendo seu próprio vazio. ${ }^{3}$

Sempre me encontro no lugar aporético da coisa escrita, não a inscrição, a escritura (o lugar almejado), mas o lugar

${ }^{3}$ SMITHSON,R. Uma Sedimentação da Mente: Projetos de Terra. 1968 disponível em COTRIM, Cecília, FERREIRA, Glória (orgs.). Escritos de Artista. Anos 60/70. Rio de Janeiro: zahar, 2006.p.191 
de encontrar no escombro das palavras uma representação própria do que foi vivido com o corpo.

As fissuras, além de possíveis falhas visíveis, se tornam a possibilidade do olhar através ou do próprio atravessamento, comprimir os cotovelos para se alojar no espaço entre um lado e o outro, a bordinha do entre dentro.

Conforto e intimidade: o que abriga.

"Moro numa velha casa de pedra - granito e xisto - na costa norte da península americana", Kenneth White ${ }^{4}$ começa um relato da casa, "Senti a necessidade de acampar um lugar, e de falar da habitação desse lugar, antes de falar de uma obra."

4 No ateliê geopoético. Disponível em http://institut-geopoetique.org/pt/textosfundadores/105-no-atelie-geopoetico
Continua, ao que posso descrever, eu mesma, do que há no fundo do vale em morada minha.

A casa de pedras, as regiões de fronteiras:

o para-raios desligado, erguido estático sobre o chão que brota piritas e a boca do rio em barro e bruma.

Geologia doméstica (nomadismo doméstico)

Lugares transitórios, se perder. Andar em círculos em estranhamento e dejà vu é uma ação nômade, como a experiência de uma fissura na experiência sensível do espaço, para além de simples deslocamentos. ${ }^{5}$

${ }^{5}$ DIAS, Karina. Entre visão e invisão: paisagem ( por uma experiência da paisagem no cotidiano). Brasília: Programa de Pós-graduação em Arte, Universidade de Brasília, 2010. 
O mapeamento começa pelos buracos.

As escavações domésticas: a estrutura própria da casa, os buracos utilitários (poços, fossas, o cemitério de animais domésticos), a qualidade da escavação da terra ela mesma, em que se descobre mais terra, porém em avesso.

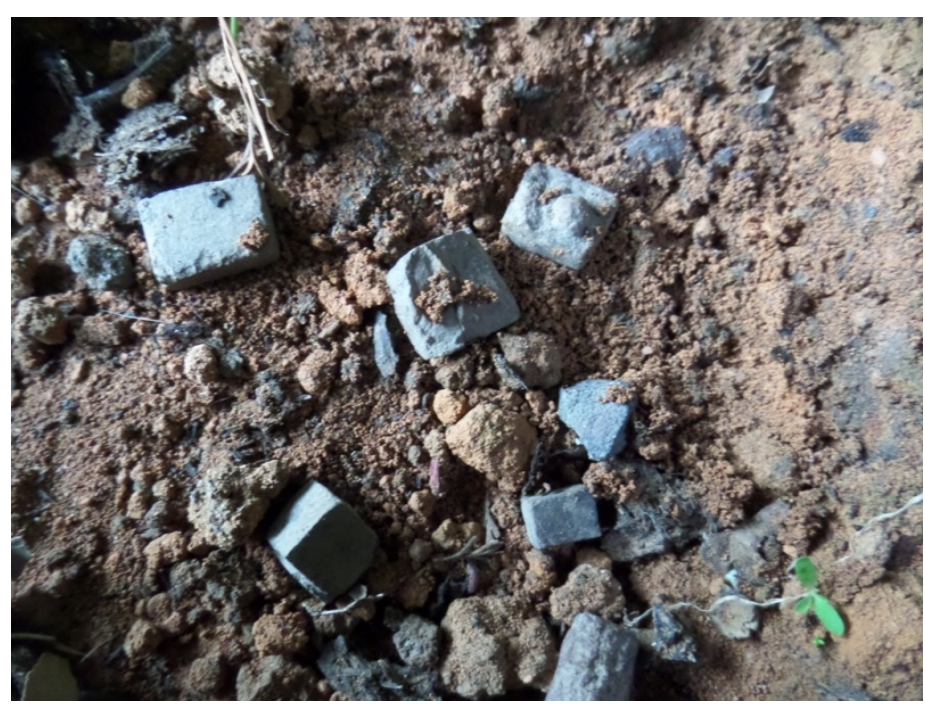

Piritas.

Danna Lua Irigaray. 2016 
Ainda na infância vivenciei minhas primeiras escavações, feitas com as mãos ou pequenas pás de plástico. Encontrei cinzeiros e sementes, revelando uma arqueologia doméstica de coisas sedimentadas no quintal, atravessadas entre tempos

A construção da casa se deu também em escavação, através do aterramento do terreno, de que se ergueram os sólidos e vigas que conferem sua geometria6 ${ }^{6}$, seu corpo.
Nos arredores da fundação, experienciei a busca por acidentes geográficos (buracos além dos escavados por ação humana nomeável) - os tropeços e cartografias de lacunas e rasgos encontrados no chão são nomeados vales, depressões no território. O território doméstico se localiza dentro do vale.

${ }^{6}$ BACHELARD, G. A poética do espaço. São Paulo: Ed. Martins fontes, 1993 
As fendas e rupturas além de mim, o vale.

Cavando buracos no quintal

tirando terra do peito

o instrumento dos avessos

Talvez olhar do jeito certo seja abandono ao tempo, ao puro movimento do mato

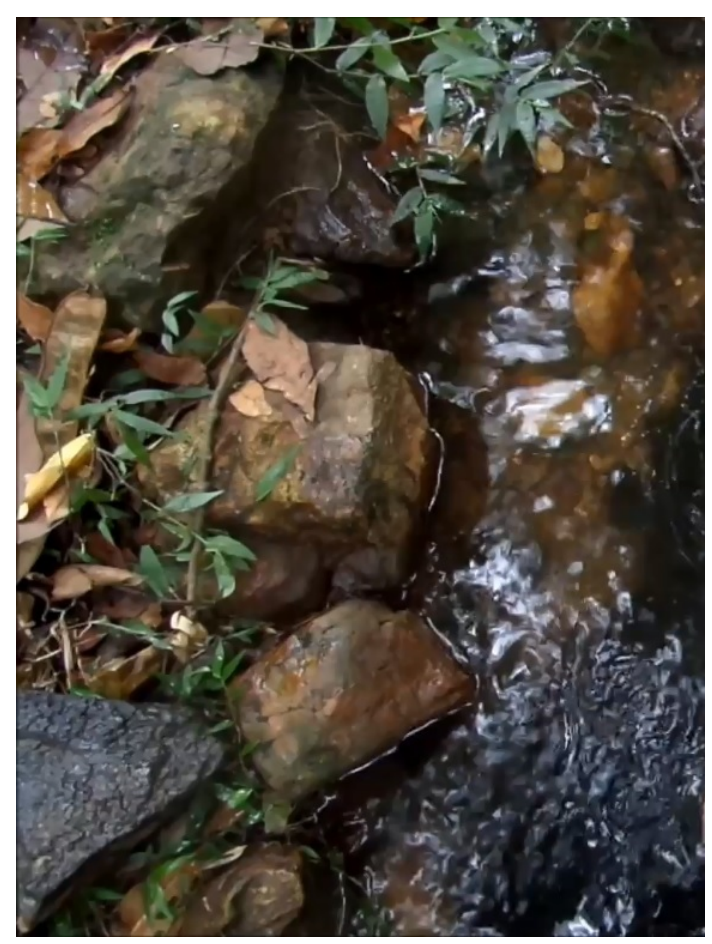

Detalhe de Dilúvios $^{7}$ 
0 jardim selvagem
Espirais de regresso à casa de onde nunca saí.

"Na palavra neve, o universo é expresso e suprimido para o ser abrigado" 8

8 BACHELARD, G. A poética do espaço. São Paulo: Ed. Martins fontes, 1993 p.57

Ter uma floresta para si.

De como chamamos Mata no vocabulário íntimo - a palavra conhecida, tateada, experimentada e o mais importante, pisada. E como nomeamos, ao Outro, em alteridade ou aparição - Floresta, a densa-escura, a que se contempla com cautela. 
A frase evoca a brancura que consome o horizonte. $O$ ser abrigado habita o dentro de casa, num lar cujo quintal está coberto de espaço negado, um espaço cujos contornos do horizonte se tornam menos definidos pela imensidão branca, esvaziado de si.

Trago então a imagem do horizonte íntimo, do verde que me cobre o fora de casa em horizontes que também se perdem, mas em distância medida. Quero trazer os respiros de verde no quarto, vidas de selva no quintal.

E a forma dessa casa oca, se linhas de paredes e árvores se confundem com a forma das palavras, estas, que só existem aqui.

A paisagem é uma imaginada, evocada e descrita: essa própria que apresento. $O$ acontecimento no sítio especifico, acontecimento em vídeo nomeado, acontecimento no texto, acontecimento na galeria. Os corpos criados por esses deslocamentos possibilitam lugares .

Um mapa mundi a partir de um jardim.

${ }^{9}$ CAUQUELIN,A. Frequentar os Incorporais. São Paulo: Ed. Martins fontes, 2008 


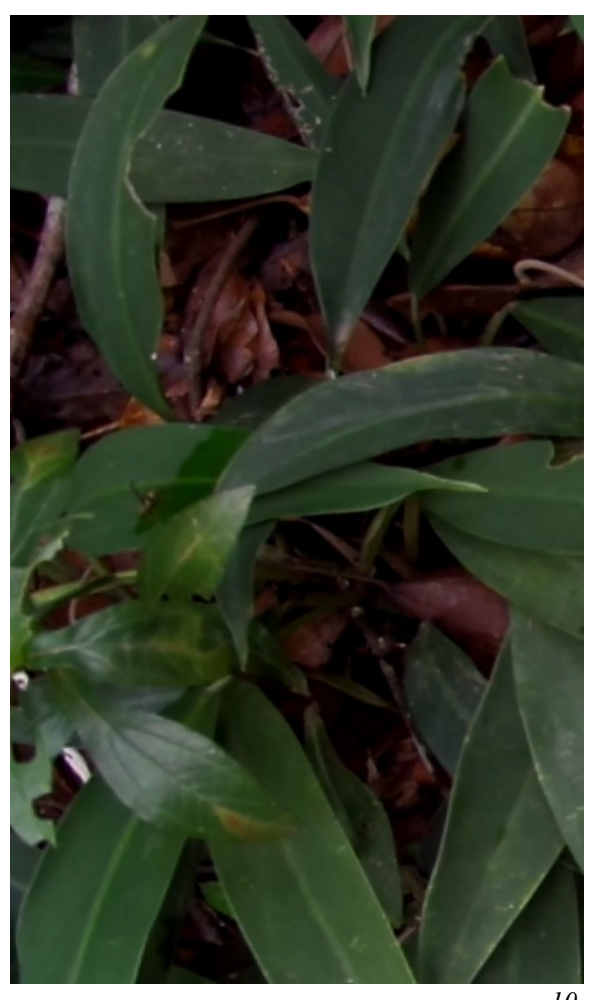

Detalhe de Selvagem: ás moscas

"(...)admirar a natureza significa olhar para fora (foris), na direção oposta à do chamado do dever, que nos impele para dentro (intus)" 11 As lentes apontadas para geografias internas e externas, a concepção da paisagem através do olho, e ainda, olhar para dentro de si, são ações com aparentes limites. Paisagem e pensamento são imagens com uma materialidade própria, se criam a partir da possibilidade de afastamento e aproximação.

${ }^{11}$ No original: "to admire nature means looking outside (foris), in the opposite direction to the call of duty, inside (intus )"

BERQUE, A. Thinking Through Landscape. Nova Iorque: Ed. Taylor \& Francis USA, 2013 p. 2 
Pela poética da terra e suas demoras, acreditava estar buscando pelo cosmos em conflito de atmosferas.

Entendi duas coisas:

1 - o corpo celeste pode cair. O lugar da queda, ou o seu quase cair me horizontalizam. A busca pelo chão é a urgência.

2- as estrelas e os raios fazem parte da mesma paisagem, ainda que em distâncias distintas, o horizonte compensa no olhar.

O horizonte que não estamos é paisagem. Se marcamos o chão que pisamos, quantos passos para trás precisamos dar para que se torne paisagem?
Pela espera da escrita, em sua feitura houveram também caminhadas. Reconheço que o texto, da mesma forma, tem sua própria prática peripatética, seu ensinamento andarilho.

Me pergunto se andarilho é a escritura aquele que lê ou a relação que se dá.

As palavras são nômades, o texto é andarilho. 


\section{Expedição \\ caminhar atento, porque o chão está mudo.}

A preocupação do andarilho é o caminho.

Nesse caminhar - que é também um respiro uma vez que se movimenta sobre retornos orgânicos - acompanhava o movimento breve das sombras e vãos de luz que via com os olhos no chão e sentia também com os pés que pisavam o trajeto e pisavam as próprias sombras, a matéria vista.

O não visto como presságio
É impossível escolher mirar somente a superfície e não evocar escavação. A escavação pode ser um estado de 
visão noturna, ou de visão queimada pelo sol. Olhar o chão e pisar o chão, e saber que inevitavelmente também, tempos e tempos estão sendo pisados mais debaixo ainda do pisar.

Pisamos a poeira, fina, a terra fofa, os pedregulhos por debaixo da terra. Ainda além, ritimitos, além, deslocamentos no tempo por meio de deslocamentos do espaço vertical de uma escavação. O que emerge do oco do chão que pressupomos quando o pisamos.

\section{Da percepção do tempo.}

A matéria do ritmo da terra, que constrói a sensação do tempo, se percebe na observação de micro movimentos do que é estático e longo - a piscadela das demoras, profundos suspiros

Na temporalidade pelo silêncio,cada dia como um respiro, o sopro é noturno.

A palavra impossível da cronologia só pode se apresentar em constelações imagéticas e sussurros de uma eternidade suspensa.

Experiência: o trajeto delirante fora de si. 
Na boca do rio e debaixo do para-raios

ISSN 2448-1246
Desta fumaça nada mais resta, para mim, do que a memória da água que ninguém mais pôde ver. 


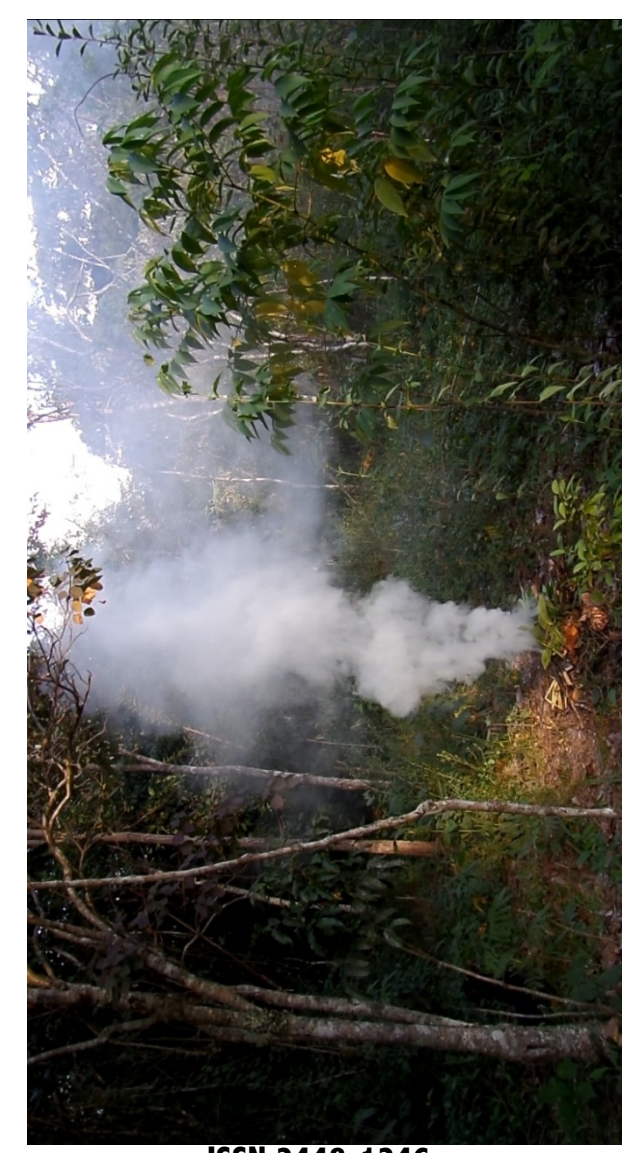

Tudo o que eu olho está atravessado pelo sol. 


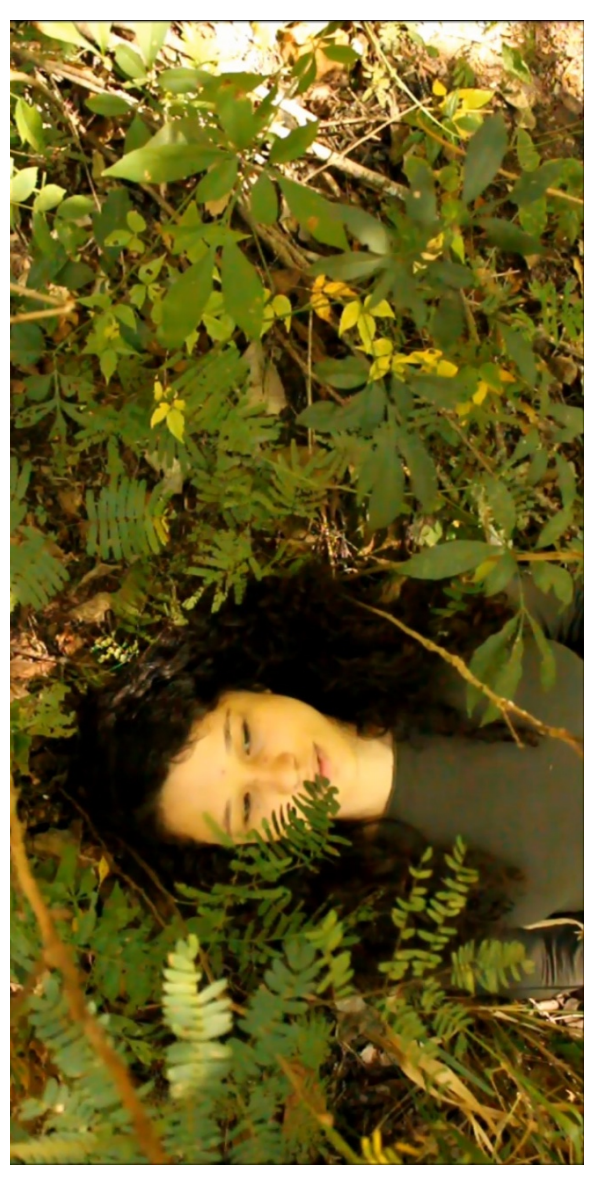

Cinza, poeira e limo. 


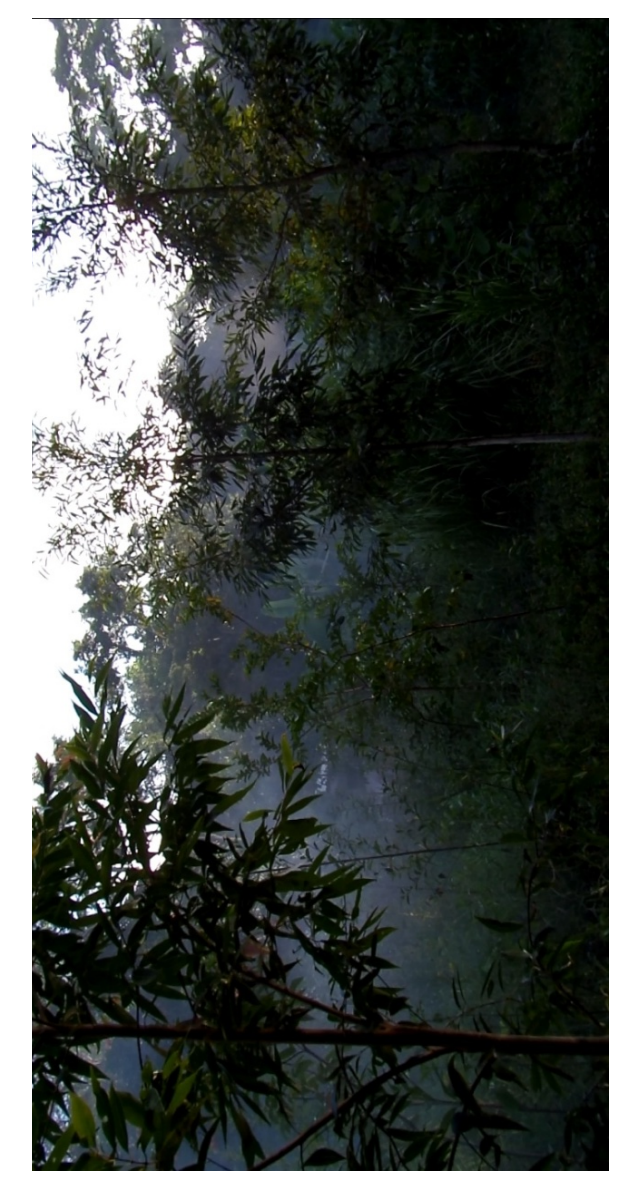

Sublime não visto,

a matéria da terra: intimidade. 
Para chegar à boca do rio, descemos ao norte.

Marrom-azul e orvalhada imagem de sombra.

O raio do Sol entre folhagens, pouco.

A frente temos estacas e uma cerca, do outro lado da margem.

Antes da água, estamos, encarando correntezas.

"a água é um corpo queimado"12

Córrego e Rio, as palavras confundem as escalas.

12 BACHELARD, G. A água e os Sonhos: Ensaio sobre a imaginação da matéria. São Paulo :Ed. Martins fontes, 1998 p.101

ISSN 2448-1246
O córrego, em finas correntes de água fria. Em épocas de chuva travam-se as enxurradas e torrentes. Em dias outros, ou nesses de céus sem nuvens, as águas se atravessam em canelas úmidas.

$\mathrm{Na}$ boca do rio - repito - onde se faz fumaça, está sempre coberto de sombras. Entre arbustos altos ele é invisível, se não prestar atenção ao rastro de seu som.

$\mathrm{Na}$ descida terrestre, sente-se o solo frio e arenoso se estiver descalço. Em porções de poeira que o pisar levanta, pedras e folhas estão cobertas e cobrem também a areia cinzenta de argila seca e macia.

Em encaramentos de fumaça e bruma, pratica-se a alteridade pela aparição.

Desaparição. Quando o mundo vira fundo a solidez é a fumaça. 
Na boca do rio há um cachorro que encara para dentro. o jardim selvagem também abriga cães que são alimentados e ainda assim caçam.
Do suave movimento do sol e vento entre as folhas e no sopro leve de bruma e fumaça, encontrei a materialidade sutil, que existe atravessada em cima da terra bruta e crua.

Encarar a existência como metade vazia, que envolve silêncios transitórios, para ser então preenchida de ausência como vivência poética.

É esta a hora das longas conversas

Das folhas com as folhas unicamente. 
É esta a hora em que o tempo é abolido

E nem sequer conheço a minha face.

(Sophia de Mello Breyner Andresen)

Entre o sul e o leste, pousa o para-raios, em subida não muito íngreme.

Seu corpo vertical, quase torre, delimita a fronteira entre vegetações: o solo árido, os rasteiros arbustos embaraçados, árvores altas e frescas e densos capinzais verdes e ásperos. Se olharmos pelos ombros vemos a fronteira, outra, em cerca.

Estamos no topo do quintal.
Debaixo do para-raios o sol está sempre a pino.

O que eu via, debaixo do para-raios, a estaticidade como possibilidade do repouso que evoca imensidão na visão ${ }^{13}$

Em repouso, pós queda, a horizontalidade do meu corpo, a "coisa estática além de seu tempo cosmológico"14

13 BACHELARD, G. A poética do espaço. São Paulo: Ed. Martins fontes, 1993 14 REDIN, M. Os meteoritos e o conceito erodido do infinito. Revista Carbono \# 5. 2013/2014 <http://www.revistacarbono.com/edicoes/05/> Acesso: maio/2016 
Buscava um encaramento que não recuasse, que olhasse além dos limites possíveis entre tela, grade, paisagem, e ali se mantivesse.

Mas o sol a pino me queimava as retinas,

E para não me cegar, desviei do outro.

Ao escolher não me cegar pelo sol e pousar os olhos na sombra, crio uma cegueira outra: a de não olhar quem me vê de volta, o espectador.

Olhar para onde não estou (no outro) me torna paisagem, o espectador em deriva: o que eu vejo não me olha.

ISSN 2448-1246

\section{Não chegar ao outro (nômade)}

Um olho de soslaio que quase olha de volta, o que vê? A fumaça que sobe irregularmente na vertical e se espalha para virar bruma.

“(...) como algo ainda não-visto e como algo que está no interior, no centro, dentro , no íntimo incluído na visão de cada um de nós." ${ }^{15}$

15 DIAS, Karina. Entre visão e invisão: paisagem ( por uma experiência da paisagem no cotidiano). Brasília: Programa de Pós-graduação em Arte,

Universidade de Brasília, 2010. P.224 
Dias apresenta o invu com o que não se vê, mas pode vir a ser visto.

Atravessam como um rio, a solidão clara de olhos que não podem mirar.

"(...) ver só se pensa e só se experimenta em última instância numa experiência do tocar" 16

Olhar para um vazio evoca que fechemos os olhos encarar o vazio como forma de cegueira que faz ver. Tudo que vemos pressupõe seus arredores.

16DIDI-HUBERMAN, G. 0 que Vemos o que nos Olha. São Paulo: Ed. 34, 1998 p. 31
Olhamos o não visto conscientes de nossos devidos arredores, e somos olhados de volta por corpos que não conhecemos.

O lugar sem corpos é um vazio. ${ }^{17}$

$\mathrm{O}$ que constitui uma paisagem, em vetores horizontais e verticais, que tremem a cada um dos nossos passos. ${ }^{18}$

17 CAUQUELIN,A. Frequentar os Incorporais. São Paulo: Ed. Martins fontes, 2008 
O chão e o teto. O perímetro do olhar de onde se pisa a onde se mira.

Olhar para onde não estou.

E onde estou, porque estive, em afrontamento e esperas que não resistem. E em cegueira, encaro ainda um outro não visto, que me cobre o céu por cima, em paisagem cósmica evocada do que pôde ser (o para-raios que não funciona)

O cosmos: o além daqui.

Os raios são daqui, em atmosfera, mas são paisagens em lentes celestes.

"Habito meu corpo e por ele habito as coisas"19

Como eu me torno, quando me esvazio do próprio corpo, há dois passos de distância do lar e da intimidade, o horizonte repara as distâncias em paisagem.

18 MERLEAU-PONTY, M. A Natureza: Curso do Collège de France.São Paulo:Ed. Martins Fontes, 2000

${ }^{19}$ MERLEAU-PONTY, M. A Natureza: Curso do Collège de France.São Paulo:Ed.

Martins Fontes, 2000 p.122

ISSN 2448-1246
As presenças cinza branco amarelado lusco fusco esverdeado, de luz, escuro, orgânico, casa, envolvem o horizonte possível, sem margens e num tempo que de começo ao fim, da base ao topo, se confundem.

E as notas, assim, terminam sua cartografia.

\section{REFERÊNCIAS}

BACHELARD, G. A poética do espaço. São Paulo: Ed. Martins fontes, 1993

BACHELARD, G. A água e os Sonhos: Ensaio sobre a imaginação da matéria. São Paulo :Ed. Martins fontes, 1998

BERQUE, A. Thinking Through Landscape. Nova lorque: Ed. Taylor \& Francis USA, 2013

CAUQUELIN,A. Frequentar os Incorporais. São Paulo: Ed. Martins fontes, 2008 
COTRIM, Cecília, FERREIRA, Glória (orgs.). Escritos de Artista. Anos 60/70. Rio de Janeiro: zahar, 2006

DIAS, Karina. Entre visão e invisão: paisagem ( por uma experiência da paisagem no cotidiano). Brasília: Programa de Pós-graduação em Arte, Universidade de Brasília, 2010.

DIDI-HUBERMAN, G. O que Vemos o que nos Olha. São Paulo: Ed. 34,1998

MERLEAU-PONTY, M. A Natureza: Curso do Collège de France.São Paulo:Ed. Martins Fontes, 2000

REDIN, M. Os meteoritos e o conceito erodido do infinito. Revista Carbono \# 5. 2013/2014

<http://www.revistacarbono.com/edicoes/05/> Acesso: maio/2016

WHITE, K. O Ateliê Geopoético. Disponível em < institutgeopoetique.org/pt/textos-fundadores/105-no-atelie-geopoetico> 